\title{
Effect of mesenchymal stromal cell infusions on lung function in COPD patients with high CRP levels
}

Daniel J. Weiss ${ }^{1 *} \mathbb{0}$, Karen Segal ${ }^{2}$, Richard Casaburi ${ }^{3}$, Jack Hayes ${ }^{4}$ and Donald Tashkin ${ }^{5}$

\begin{abstract}
Background: We previously reported a Phase $1 / 2$ randomized placebo-controlled trial of systemic administration of bone marrow-derived allogeneic MSCs (remestemcel-L) in COPD. While safety profile was good, no functional efficacy was observed. However, in view of growing recognition of effects of inflammatory environments on MSC actions we conducted a post-hoc analysis with stratification by baseline levels of a circulating inflammatory marker, C-reactive protein (CRP) to determine the effects of MSC administration in COPD patients with varying circulating CRP levels.
\end{abstract}

Methods: Time course of lung function, exercise performance, patient reported responses, and exacerbation frequency following four monthly infusions of remestemcel-L vs. placebo were re-assessed in subgroups based on baseline circulating CRP levels.

Results: In COPD patients with baseline CRP $\geq 4 \mathrm{mg} / \mathrm{L}$, compared to COPD patients receiving placebo $(\mathrm{N}=17)$, those treated with remestemcel-L $(N=12)$, demonstrated significant improvements from baseline in forced expiratory volume in one second, forced vital capacity, and six minute walk distance at 120 days with treatment differences evident as early as 10 days after the first infusion. Significant although smaller benefits were also detected in those with CRP levels $\geq 2$ or $\geq 3 \mathrm{mg} / \mathrm{L}$. These improvements persisted variably over the 2 -year observational period. No significant benefits were observed in patient reported responses or number of COPD exacerbations between treatment groups.

Conclusion: In an inflammatory environment, defined by elevated circulating CRP, remestemcel-L administration yielded at least transient meaningful pulmonary and functional improvements. These findings warrant further investigation of potential MSC-based therapies in COPD and other inflammatory pulmonary diseases.

Trial registration: Clinicaltrials.gov NCT00683722.

Keywords: Mesenchymal stromal cells, Chronic obstructive pulmonary disease, Inflammation, Pulmonary function, C-reactive protein

\section{Background}

Chronic obstructive pulmonary disease (COPD) is currently the fourth-ranked overall cause of death globally, with more than 120,000 attributable deaths annually in the United States [1]. COPD is characterized by a

\footnotetext{
*Correspondence: dweiss@uvm.edu

${ }^{1}$ University of Vermont College of Medicine, 226 Health Science Research Facility, Burlington, VT 05405, USA
}

Full list of author information is available at the end of the article spectrum of clinical and pathophysiologic manifestations, but common features include chronic airway inflammation and progressive destruction of lung parenchyma. Currently, apart from lung transplantation, there are no curative treatments and available therapies are geared towards symptomatic relief. Owing to the high prevalence and chronic nature of the disease, COPD management has high resource utilization with frequent clinician visits, hospitalizations due to acute exacerbations, and 
requirement of chronic oxygen and pharmacologic therapies [1].

Recent advances in cell-based therapies for lung diseases provide a platform for development of new therapeutic approaches to acute lung diseases and critical illnesses and possibly also for chronic inflammatory pulmonary conditions including COPD [2, 3]. Mesenchymal stromal cell (MSC)-based therapies have shown promise in a range of pre-clinical lung injury models, including those for COPD [4], due to their immunomodulatory properties (reviewed in 4). However, while systemic MSC administration has proven safe and well-tolerated in clinical investigations, there has been no clear evidence of efficacy to date in a spectrum of lung disease patients studied including those with COPD [5-7]. We previously reported results of a placebo-controlled trial [NCT00683722] of systemic infusions of bone marrowderived allogeneic MSCs in patients with moderate to severe COPD that included 62 patients with moderate or severe COPD (GOLD spirometry stage 2 or stage 3 ) randomized at six participating sites to double-blinded intravenous infusions of remestemcel-L, formerly Prochymal $^{\mathrm{TM}},\left(10^{8}\right.$ cells/ infusion) or vehicle control [8]. All subjects received four monthly infusions and were followed for two years after the first infusion. Endpoints included safety assessments, pulmonary function testing, six-minute walk distance (6MWD), frequency of subsequent COPD exacerbations, and patient reported outcome surveys (Borg dyspnea score, St. George Respiratory Questionnaire). Circulating inflammatory biomarkers, including $\mathrm{C}$-reactive protein (CRP), were assessed at baseline and over time. Remestemcel-L was well tolerated with no infusional toxicities and no attributable serious adverse events causally related to treatment as assessed by study investigators. However, there were no statistically significant differences between remestemcel- $\mathrm{L}$ and placebo-treated subjects in the pulmonary function, functional capacity, or patient-reported outcome measures. One novel observation was that, in patients with elevated baseline CRP levels at study entry, a statistically significant CRP decrease was observed over the initial months of the study in patients receiving remestemcel-L compared to placebo, and a non-significant trend persisted over the two year observation period.

Since that study was reported, there has been growing appreciation that the function of systemically administered MSCs can be significantly affected by the inflammatory environment they encounter [9-13]. This can manifest as a change in the portfolio of secreted mediators and subsequent downstream actions on relevant inflammatory cells, including macrophages and neutrophils, important in COPD pathogenesis. Circulating CRP is frequently elevated in COPD patients and is associated with higher mortality, worse outcomes after a COPD exacerbation, and for a higher rate of hospital readmission [14-17]. Although patients with any recent exacerbations were excluded from participating in the study, there was a subgroup with elevated circulating CRP levels at baseline, suggestive of a more inflammatory and exacerbation-prone phenotype. We therefore performed a graded post-hoc analysis of functional outcomes from the original investigation based on stratification of circulating CRP levels.

\section{Methods}

Complete study methods including inclusion/exclusion criteria and study assessments are described in detail in the original report [8]. In brief, 62 patients with moderate to severe COPD were randomized to receive 4 monthly infusions of either remestemcel-L or of vehicle control (placebo). The patients were subsequently followed for a 2 year period for safety and potential efficacy. Additional evaluations included measure of circulating mediators including $\mathrm{C}$-reactive protein (CRP). The protocol was approved by the institutional review board at each participating center and written informed consent was obtained from each participant. For the current post-hoc analyses, the full sample of patients who participated in the original study (receiving all four monthly infusions) was stratified into those with serum CRP levels of either $\geq 4 \mathrm{mg} / \mathrm{L}$ or $<4 \mathrm{mg} / \mathrm{L}$ at study entry (baseline). This cut-point was determined empirically based on an observation in the primary paper that patients with CRP levels $\geq 4 \mathrm{mg} / \mathrm{L}(\mathrm{n}=29)$ at baseline showed a statistically significant decrease in CRP at 30 days after the first infusion in MSC-treated patients [8]. Additional sensitivity analyses were applied to evaluate lower cut-points; baseline CRP $\geq 2(n=35)$ or $\geq 3(n=42) \mathrm{mg} / \mathrm{L})$. Differences between patients receiving remestemcel-L or placebo in each stratified cohort were assessed with respect to changes from baseline in the pulmonary, functional, and patient-reported outcome variables: forced expiratory volume in $1 \mathrm{~s}\left(\mathrm{FEV}_{1}\right)$, forced vital capacity (FVC), total lung capacity (TLC), diffusing capacity for carbon monoxide $\left(\mathrm{D}_{\mathrm{L}} \mathrm{CO}\right), 6$ min walk distance $(6 \mathrm{MWD})$, number of COPD exacerbations over the 2-year observation period, Borg dyspnea score, and the St. George Respiratory Questionnaire (SGRQ) total score. The study treatment infusions were administered on study days 0 (baseline), 30, 60 and 90. Efficacy assessments were performed at study days $0,10,30,60,90,120,150,180,360$ and 720 (TLC only at days 0 and 180). The frequency of assessments for each efficacy variable are described in detail in the original publication. Changes over time in levels of circulating CRP were also re-assessed in the stratified cohorts at each study visit. For clarification: all circulating 
CRP levels were measured in the same centralized laboratory using a high sensitivity assay [8].

Changes from baseline over time in spirometric variables $\left(\mathrm{FEV}_{1}, \mathrm{FVC}\right)$ and in 6MWD were assessed using the mixed model for repeated measures analysis of variance (MMRM) to assess overall treatment effects across all visits as well as at each visit separately. The imputation used by the procedure is based on assumption of the missing at random (MAR). An unstructured covariance matrix was used for the MMRM analysis, unless the model does not converge, in which case the compound symmetry covariance matrix was used [18]. A sensitivity test of the difference between remestemcel- $\mathrm{L}$ and placebo at day 120 was conducted using Student $t$-tests for independent groups. Day 120 was chosen as 30 days after last infusion was anticipated to be sufficient time to see effect of treatment. Differences between groups in the proportion of subjects with none/one or two or more COPD exacerbations were tested using a Chi-square test for differences between two proportions. All statistical analyses were performed using two-sided hypothesis tests at the 0.05 level of significance. Data were analyzed using SAS release 9.4 and GraphPad Prism version 8.3.

\section{Results}

Baseline demographic and disease characteristics for subjects with baseline $\mathrm{CRP} \geq 4 \mathrm{mg} / \mathrm{L}$ and $<4 \mathrm{mg} / \mathrm{L}$ are shown in Table 1 . There were no significant differences between treatment groups in any of the baseline variables based on this stratification. Mean baseline CRP levels $( \pm \mathrm{SD})$ in subjects with baseline $\mathrm{CRP} \geq 4 \mathrm{mg} / \mathrm{L}$ were $16.3 \pm 17.2$ and $10.3 \pm 9.17$, and median CRP levels were 10.5 and 7.8 respectively in the remestemcel- $\mathrm{L}(\mathrm{N}=12)$ and placebo $(\mathrm{N}=17)$ groups; in subjects with baseline $\mathrm{CRP}<4 \mathrm{mg} / \mathrm{L}$ mean baseline CRP values were $1.9 \pm 1.2$ and $1.7 \pm 0.95 \mathrm{mg} / \mathrm{L}$ and median values were 1.4 and 1.7 in the remestemcel- $\mathrm{L}(\mathrm{N}=18)$ and placebo $(\mathrm{N}=15)$ groups, respectively. The mean CRP values differ $\sim$ sevenfold between CRP strata. Within each CRP stratum, baseline CRP levels were similar in the remestemcel-L and placebo groups.

Changes over the 2-year study period in $\mathrm{FEV}_{1}, \mathrm{FVC}$, and 6MWD, and in circulating CRP levels in subjects with baseline $\mathrm{CRP} \geq 4 \mathrm{mg} / \mathrm{L}$ in those receiving remestemcel-L vs. placebo are shown in Figs. 1 and 3, respectively. Remestemcel-L-treated patients had significant improvements or stabilization of both $\mathrm{FEV}_{1}$ and $6 \mathrm{MWD}$ as early as 10 days after the first of four monthly study drug infusions. The improvement in $\mathrm{FEV}_{1}$ (Fig. 1a) relative to placebo was significant over the 2-year study period as assessed by the mixed model with repeated measures $(P=0.003)$ with specific significant differences observed at day 120 as assessed by the least squares mean at this timepoint $(\mathrm{P}=0.015)$. Improvement in 6MWD (Fig. 1c) persisted through 120 days and a significant trajectory compared to placebo was evident over the entire 2-year study period $(P=0.006$ overall; $\mathrm{P}=0.004$ at day 120 ). In contrast, placebotreated patients showed a progressive overall decrease in both $\mathrm{FEV}_{1}$ and $6 \mathrm{MWD}$ over the 2-year study period (Fig. 1). FVC stabilized over the first 120 days in remestemcel-L-treated as compared to progressive decline in placebo treated patients (Fig. 1b). Although the overall change from baseline by MMRM was not significant for FVC $(\mathrm{P}=0.19)$, isolated significance compared to placebo was observed at day $120(\mathrm{P}=0.005$. $)$ However, after 180 days, both groups showed similar progressive declines. There were no significant changes in total lung capacity at day 180 or in $\mathrm{D}_{\mathrm{L}} \mathrm{CO}$ in patients with baseline CRP $\geq 4 \mathrm{mg} / \mathrm{Lin}$ either the remestemcel$\mathrm{L}$ or placebo groups. In contrast to the effects noted in patients with baseline $C R P \geq 4$, in patients with baseline $\mathrm{CRP}<4 \mathrm{mg} / \mathrm{L}$ overall there were no significant differences overall or at any visit between treatment groups in $\mathrm{FEV}_{1}$ and $\mathrm{FVC}$, and no significant differences in 6MWD except at day 10 and day 90, which favored placebo (Fig. 2).

For patients with baseline CRP $\geq 4 \mathrm{mg} / \mathrm{L}$ there was a trend towards reductions in CRP levels over the first 180 days in the remestemcel-L-treated compared with placebo-treated subjects (Fig. 3a). However, these did not correlate with the observed changes in $\mathrm{FEV}_{1}, \mathrm{FVC}$, or $6 \mathrm{MWD}$. For patients with $\mathrm{CRP}<4 \mathrm{mg} / \mathrm{L}$ there was no difference between treatment groups in CRP levels except at Day 180 in favor of the placebo group (Fig. 3b). There were no significant changes or differences in the number of COPD exacerbations, Borg dyspnea score, or SGRQ results between patients treated with remestemcel-L vs. placebo in either CRP stratum. To explore further the influence of circulating CRP levels on $\mathrm{FEV}_{1}$, $\mathrm{FVC}$, and $6 \mathrm{MWD}$, patients were further stratified into those with levels of either $\geq$ or $<$ than 3 or $2 \mathrm{mg} / \mathrm{L}$ at baseline. Values were assessed on Day 120, the time point at which the greatest differences between MSC vs. placebo treated patients were observed when stratified for CRP levels $\geq$ or $<4 \mathrm{mg} / \mathrm{L}$. Notably, improvements in $\mathrm{FEV}_{1}, \mathrm{FVC}$, and 6MWD in remestemcel-L- vs placebotreated patients were also observed in those with baseline $\mathrm{CRP} \geq 3 \mathrm{mg} / \mathrm{dl}$ (Table 2). Comparative improvements in FVC in remestemcel-L- vs placebo-treated patients were further observed in those with baseline CRP $\geq 2 \mathrm{mg} / \mathrm{dl}$ while those for $\mathrm{FEV}_{1}$ and $6 \mathrm{MWD}$ were no longer significant $(\mathrm{p}<0.055$ and $\mathrm{p}<0.159$, respectively). There was no change in number of COPD exacerbations over the 2 year study period between remestemcel-L- vs placebo-treated patients when stratified for $\mathrm{CRP} \geq$ or $<4 \mathrm{mg} / \mathrm{dl}$ (Table 3). 
Table 1 Demographic and disease characteristics: A. subjects with baseline CRP $\geq 4 \mathrm{mg} / \mathrm{L}$ and $\mathrm{B}$. subjects with baseline CRP $<4 \mathrm{mg} / \mathrm{L}$

\section{A. Subjects with baseline CRP $\geq 4 \mathrm{mg} / \mathrm{L}$}

Placebo $(n=17)$

Remestemcel-L $(n=12)$

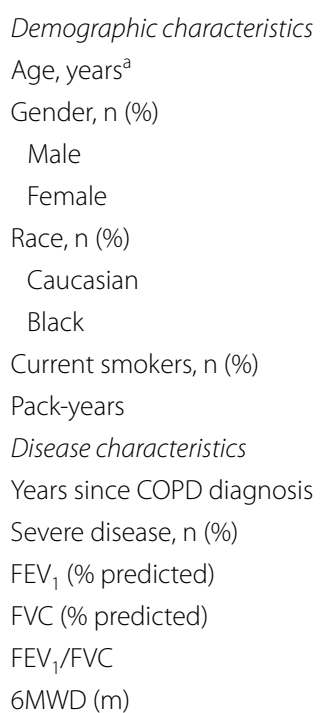

$65.0(7.7)$

$8(47 \%)$

$9(53 \%)$

15 (88\%)

$2(12 \%)$

$5(29 \%)$

$64.8(19.0)$

$8.9(6.4)$

$12(70.6 \%)$

$45.6(12.7)$

78.9 (18.9)

$317.7(95.0)$
$0.442(0.1)$

$69.3(5.9)$

$7(58 \%)$

$5(42 \%)$

$11(92 \%)$

$1(8 \%)$

$2(17 \%)$

$54.2(17.2)$

$6.6(3.3)$

$8(66.7 \%)$

$45.6(14.8)$

74.6 (11.6)

$0.451(0.12)$

280.6 (117.8)

\section{B. Subjects baseline CRP $<4 \mathrm{mg} / \mathrm{L}$}

Placebo $(n=15)$

Remestemcel-L $(n=18)$

Demographic characteristics

Age, years ${ }^{\text {a }}$

$62.9(10.0)$

$67.3(8.5)$

Gender, n (\%)

Male

$10(66.7)$

11 (61.1)

Female

5 (33.3)

7 (38.9)

Race, n (\%)

Caucasian

$1313(86.7)$

$18(100)$

Black

$1(6.7)$

Asian

$1(6.7)$

$7(46.67)$

$3(16.7)$

$50.9(23.4)$

$57.1(23.7)$

Pack-years

$6.2(6.2)$

$9.2(4.8)$

$9(60.0)$

$12(66.7)$

$47.3(12.9)$

$44.8(12.6)$

$78.9(18.9)$

74.6 (11.6)

$0.49(0.15)$

$0.43(0.08)$

372.5 (91.1)

GMWD (m)

forced vital capacity, 6MWD 6 min walk distance

CRP C-reactive protein, $F E V$, forced expiratory
a Values are mean (SD) unless otherwise noted

(See figure on next page.)

Fig. 1 Changes from baseline in pulmonary function and functional performance from baseline in subjects with baseline CRP $>\underline{4} \mathrm{mg} / \mathrm{L}$. Overall treatment effect across all visits were assessed by mixed model with repeated measures (MMRM). Simple differences of treatment by visit are

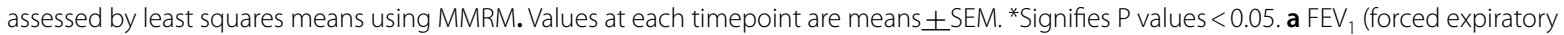
volume:) $P=0.003$ overall by MMRM across all visits and $P=0.015$ at day 120 . b FVC (forced vital capacity): $P=0.19$ overall by MMRM across all visits and $P=0.005$ at day 120. c 6MWD (six-minute walk distance): $P=0.0006$ overall by MMRM across all visits and $P=0.004$ at day 120 

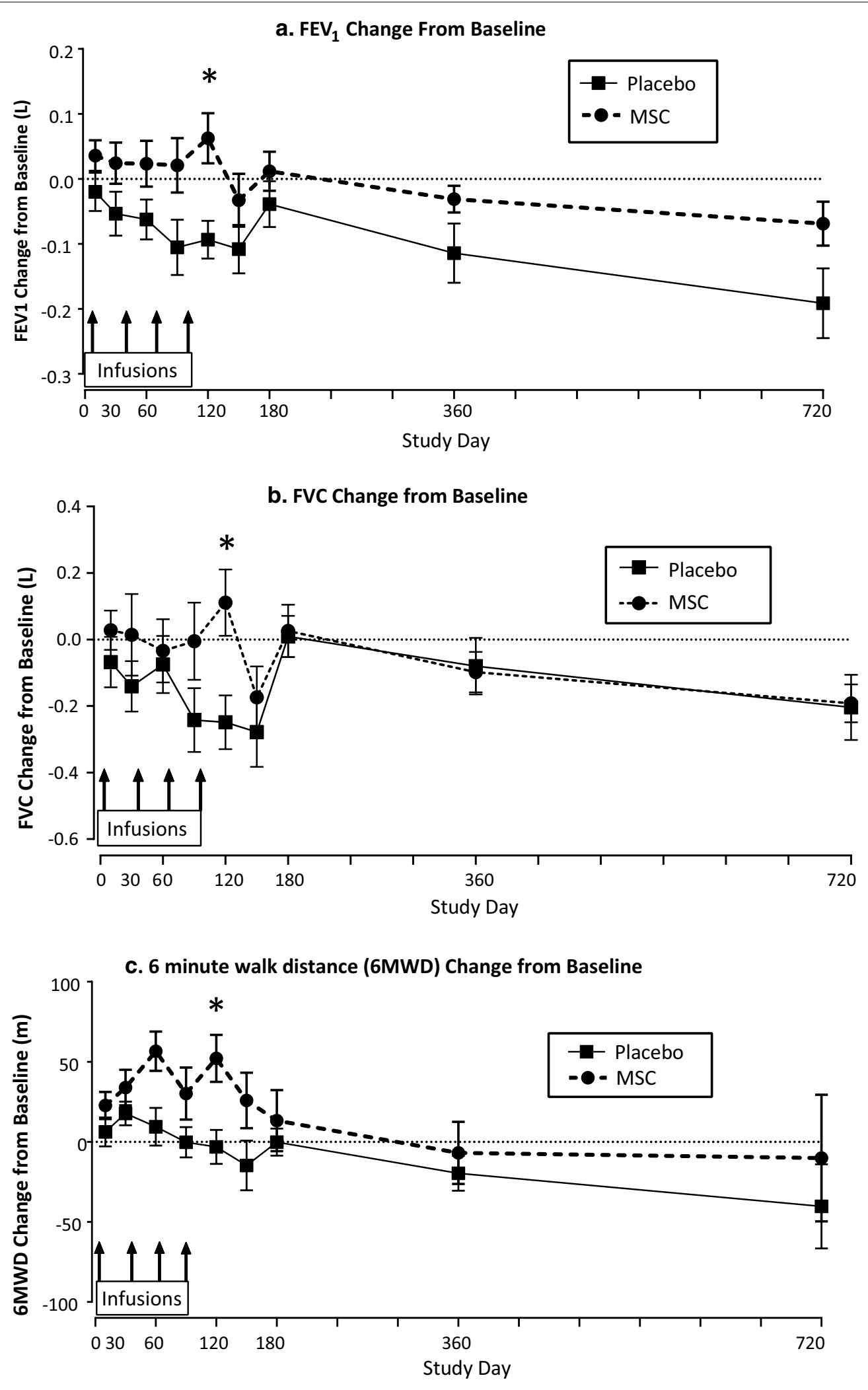


\section{Discussion}

Post-hoc, hypothesis-generating analyses of a previously conducted investigation of systemic MSC administration in patients with moderate-severe COPD have demonstrated previously unrecognized efficacy in those with more systemic inflammation at study entry. Importantly, beneficial effects over time were observed in the clinically relevant functional outcomes $\mathrm{FEV}_{1}, \mathrm{FVC}$, and 6MWD. Notably, at 120 days, the magnitude of these differences exceeded the meaningful clinically important differences for both $\mathrm{FEV}_{1}$ and 6MWD and thus have significant clinical implications. [18, 19] There was a corresponding, albeit non-significant, trend towards decrease in systemic inflammation as assessed by serial measurements of circulating CRP levels in remestemcel-L treated patients but this, however, did not correlate with changes in the functional outcomes. Improvements in these outcomes also appeared to hold when patients were stratified for lower levels of systemic inflammation.

The biological rationale for investigation of potential salutary effects of MSCs in COPD is based on the premise that secretion of multiple paracrine factors including anti-inflammatory cytokines and growth factors that thereby facilitate tissue repair may counter or potentially even reverse chronic inflammation and lung destruction. However, studies to date of MSC administration in COPD patients have consistently demonstrated safety but not efficacy [5-8]. Other studies have further demonstrated safety but were not designed to assess efficacy when MSCs were administered to study effects on systemic immune responses in COPD patients [20]. A recent phase 1 study assessing safety efficacy of MSC administration for potential treatment of inflammation resulting from endobronchial valve placement in COPD patients was not designed to assess specific effects on COPD clinical course [21]. However, this study also demonstrated a decrease in circulating CRP in patients who received MSCs. These results are in contradistinction to a body of literature in pre-clinical models of emphysema, including those resulting from elastase, papain, and cigarette-smoke induced inflammation and damage, in which MSC administration may have beneficial effects [5, 2244]. Acknowledging the strengths and imitations of each of these models for fidelity to human disease, a variety of mechanisms have been postulated for MSC actions. Many of these focus on disruption of inflammatory pathways activated or provoked in the different models and highlight increasing recognition that MSCs may have better potential therapeutic effects in more inflammatory lung environments [2]. Notably, MSCs are increasingly recognized to sense the inflammatory environment through damage- and pathogen-associated molecular pathogen receptors, e.g. Toll-Like receptors, and respond by releasing specific sets of anti-inflammatory cytokines, anti-bacterial peptides, extracellular vesicles containing anti-inflammatory miRNAs, mitochondria, and other potential mediators. [4, 9-13, 44-49].

As such, we postulate that a subset of patients in the COPD spectrum may be more likely to respond to MSC-based administration, i.e., those with more pronounced chronic inflammation. This has not as yet been directly or prospectively addressed in clinical investigations to date. However, the findings from the post-hoc analyses presented in the current analyses are both mechanistically hypothesis generating and also powerful stimuli to prospectively re-assess potential efficacies of MSC-based cell therapies in carefully stratified patient groups. Accordingly, future studies may focus on patients with high levels of circulating inflammatory cytokines including IL-6, IL-1 and TNF- $\alpha$ as well as CRP to investigate further the clinical efficacy and impact of inflammatory cytokines on cell-based therapies. In the primary analysis of this study, levels of inflammatory cytokines other than for CRP were below the level of detection in most subjects, perhaps due to assay methods that lacked sufficient sensitivity, and high sensitivity CRP will need to be further assessed in future studies [8]. Limitations of this report include the post-hoc nature of the analysis, the lack of data regarding other inflammatory cytokines to confirm the CRP observations and the relatively small sample size. Further, as documented in the original report, review of patients' diaries kept during the investigation revealed that reliever/rescue medication use was not systematically recorded and it was not possible to do the planned analyses on home medication use including home oxygen. These deserve re-investigation in future prospective studies as will a wider range of inflammatory markers including, for example, circulating receptor for advanced glycation endproducts (RAGE). A review of corticosteroid use revealed that only a small number of patients were on

\footnotetext{
(See figure on next page.)

Fig. 2 Changes from baseline in pulmonary function and functional performance from baseline in subjects with baseline CRP $<\underline{4} \mathrm{mg} / \mathrm{L}$. Overall treatment effect across all visits were assessed by mixed model with repeated measures (MMRM). Simple differences of treatment by visit are assessed by least squares means using MMRM. Values at each timepoint are means + SEM. *Signifies $P$ values $<0.05$. a FEV 1 (forced expiratory volume:) $\mathrm{P}=\mathrm{ns}$ overall by MMRM across all visits. $\mathbf{b}$ FVC (forced vital capacity): $\mathrm{P}=\mathrm{ns}$ overall by MMRM across all visits. $\mathbf{c} 6 \mathrm{MWD}$ (six-minute walk distance): $P=$ ns overall by MMRM across all visits and $P<0.05$ at day 10 and day 90
} 

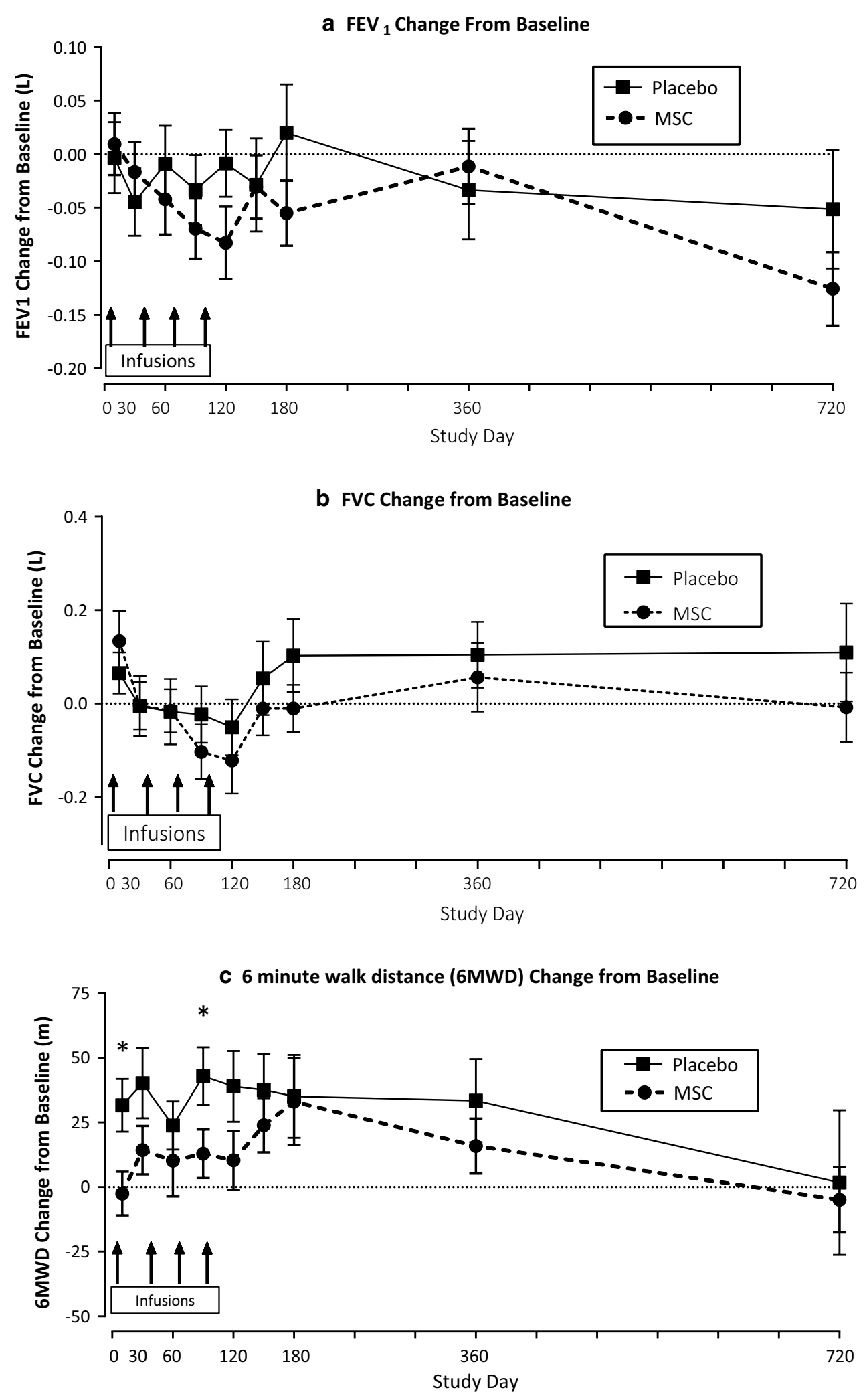

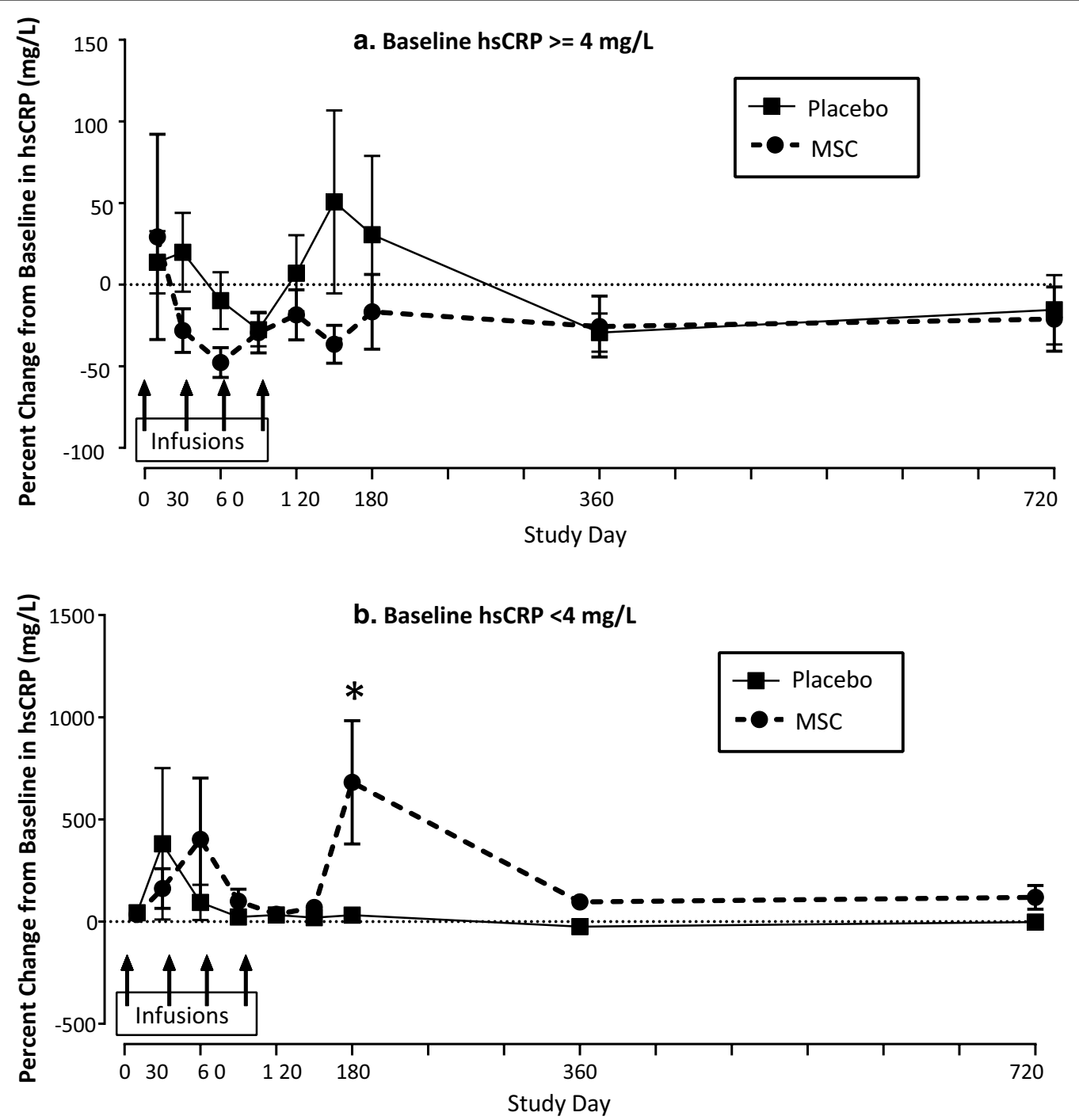

Fig. 3 Percent change from baseline in C-reactive protein (CRP) in subjects with baseline CRP $\geq 4 \mathrm{mg} / \mathrm{L}$ (panel a) and $<4 \mathrm{mg} / \mathrm{L}$ (panel b). Overall treatment effect across all visits using mixed model with repeated measures (MMRM). There were no significant differences between treatment groups overall or at any individual timepoint except as noted. Values are means \pm SEM. *Signifies P value $<0.05$

these at study entry, some for conditions other than COPD. This is a parameter that will be investigated further in prospective studies. Further, other conditions may also contribute to fluctuations in CRP and may thus explain the observed variability. Knowledge of how MSCs are acting in different disease environments is also evolving including further appreciation of host responses to systemic administration of allogeneic MSCs [9, 50-52]. Nonetheless, these findings are suggestive and hypothesis-generating for confirmation in future studies.

\section{Conclusion}

In summary, stratification of COPD patients by elevated baseline CRP level identified patients that responded to remestemcel-L treatment with improvements in pulmonary and overall physical function. A trend for an association between highest CRP levels and degree of clinical response suggests that the inflammatory component of COPD may amplify potential beneficial immunomodulatory effects of remestemcel-L administration in COPD. Future studies will be needed to investigate this in greater detail. 
Table 2 Day 120 efficacy analysis by baseline CRP subgroups (sensitivity analysis)

\section{Placebo MSC Difference P-value}

\begin{tabular}{|c|c|c|c|c|}
\hline & & & & \\
\hline \multicolumn{5}{|l|}{ Subgroup/parameter } \\
\hline Baseline CRP $\geq 4 \mathrm{mg} / \mathrm{L}$ & $N=17$ & $N=12$ & & \\
\hline \multicolumn{5}{|c|}{ Mean change from baseline: } \\
\hline $\mathrm{FEV}_{1}(\mathrm{~L})$ & -0.094 & 0.063 & 0.156 & 0.003 \\
\hline FVC (L) & -0.249 & 0.111 & 0.360 & 0.009 \\
\hline $6 \mathrm{MWD}(\mathrm{m})$ & -3.118 & 52.167 & 55.284 & 0.004 \\
\hline Baseline CRP $<4 \mathrm{mg} / \mathrm{L}$ & $N=15$ & $N=18$ & & \\
\hline \multicolumn{5}{|c|}{ Mean change from baseline: } \\
\hline $\mathrm{FEV}_{1}(\mathrm{~L})$ & -0.009 & -0.083 & -0.074 & 0.123 \\
\hline $\mathrm{FVC}(\mathrm{L})$ & -0.051 & -0.122 & -0.071 & 0.461 \\
\hline $6 \mathrm{MWD}(\mathrm{m})$ & 38.933 & 10.333 & -28.600 & 0.116 \\
\hline Baseline CRP $\geq 3 \mathrm{mg} / \mathrm{L}$ & $N=21$ & $N=14$ & & \\
\hline \multicolumn{5}{|c|}{ Mean change from baseline: } \\
\hline $\mathrm{FEV}_{1}(\mathrm{~L})$ & -0.074 & 0.051 & 0.125 & 0.009 \\
\hline $\mathrm{FVC}(\mathrm{L})$ & -0.217 & 0.109 & 0.326 & 0.006 \\
\hline $6 \mathrm{MWD}(\mathrm{m})$ & 5.952 & 42.571 & 36.619 & 0.040 \\
\hline Baseline CRP $<3 \mathrm{mg} / \mathrm{L}$ & $N=11$ & $N=16$ & & \\
\hline \multicolumn{5}{|c|}{ Mean change from baseline: } \\
\hline $\mathrm{FEV}_{1}(\mathrm{~L})$ & -0.015 & -0.091 & -0.076 & 0.165 \\
\hline FVC (L) & -0.041 & -0.149 & -0.109 & 0.333 \\
\hline $6 \mathrm{MWD}(\mathrm{m})$ & 36.909 & 13.500 & -23.409 & 0.270 \\
\hline Baseline CRP $\geq 2 \mathrm{mg} / \mathrm{L}$ & $N=23$ & $N=19$ & & \\
\hline \multicolumn{5}{|c|}{ Mean change from baseline: } \\
\hline $\mathrm{FEV}_{1}(\mathrm{~L})$ & -0.073 & 0.009 & 0.083 & 0.055 \\
\hline FVC (L) & -0.199 & 0.042 & 0.241 & 0.022 \\
\hline $6 \mathrm{MWD}(\mathrm{m})$ & 8.391 & 31.632 & 23.241 & 0.159 \\
\hline Baseline $C R P<2 \mathrm{mg} / \mathrm{L}$ & $N=9$ & $N=11$ & & \\
\hline \multicolumn{5}{|c|}{ Mean change from baseline: } \\
\hline $\mathrm{FEV}_{1}(\mathrm{~L})$ & -0.004 & -0.084 & -0.079 & 0.235 \\
\hline FVC (L) & -0.047 & -0.150 & -0.103 & 0.435 \\
\hline $6 \mathrm{MWD}(\mathrm{m})$ & 37.556 & 19.182 & -18.374 & 0.444 \\
\hline
\end{tabular}

CRP C-reactive protein, FEV 1 forced expiratory volume-one second, FVC forced vital capacity, 6MWD 6-min walk distance

a $\mathrm{P}$-value for difference between placebo and remestemcel-L groups by Student t-test for independent groups

Table 3 Number (percent) of COPD exacerbations per patient by treatment group for subjects with baseline $C R P \geq 4 \mathrm{mg} / \mathrm{L}$ and $<4 \mathrm{mg} / \mathrm{L}$

\begin{tabular}{|c|c|c|c|}
\hline $\begin{array}{l}\text { COPD exacerbations } \\
\text { per patient }\end{array}$ & & 0 or 1 & $\leq 2$ \\
\hline \multirow[t]{2}{*}{ Baseline COPD $\geq 4 \mathrm{mg} / \mathrm{L}$} & Placebo $\mathrm{N}=17$ & $11(65)$ & $6(35)$ \\
\hline & Remestemcel-L N=12 & $10(83)$ & $2(17)$ \\
\hline \multirow[t]{2}{*}{ Baseline COPD < 4 mg/L } & Placebo $\mathrm{N}=15$ & $13(87)$ & $2(13)$ \\
\hline & Remestemcel-L N $=18$ & $12(67)$ & $6(33)$ \\
\hline
\end{tabular}

COPD chronic obstructive lung disease, CRP C-reactive protein

\section{Acknowledgements}

The authors acknowledge Olga Rutman for assistance with the statistical analyses.

\section{Authors' contributions}

DJW, RC, DT designed experiments, performed experiments, analyzed results, interpreted results, and co-wrote the manuscript. KS assisted in post-hoc data analyses, prepared tables and figures, and co-wrote the manuscript. JH participated in the conception, analysis and interpretation of data. All authors read and approved the final manuscript.

\section{Funding}

Role of the sponsor (Mesoblast, Inc.): No financial or other support provided.

\section{Availability of data and materials}

The datasets used and/or analysed during the current study were initially published in Weiss et al., A placebo-controlled, randomized trial of mesenchymal stem cells in COPD. Chest. 2013;143(6):1590-8 and are available from the corresponding author on reasonable request.

\section{Declarations}

Ethics approval and consent to participate

The protocol was approved by the institutional review board at each participating center and written informed consent was obtained from each participant.

\section{Consent for publication}

Not applicable.

\section{Competing interests}

DJW receives research support from the NIH, Department of Defense, Cystic Fibrosis Foundation, and the University of Vermont. RC is a member of the speaker's bureau for Glaxo Smith Kline, is a consultant for Genentech, Regeneron and Boehringer Ingelheim and is an advisory board member for Astra Zeneca. His laboratory receives research support from Regeneron, Genentech, Boehringer Ingelheim and Glaxo Smith Kline. KS is a former employee of Mesoblast Inc. and JH is a current employee of Mesoblast Inc. DPT is an advisory board member and speaker for AstraZeneca and Mylan/Theravance. DJW, $\mathrm{RC}$, and DPT had previous research support from Osiris Therapeutics, Inc.

\section{Author details}

${ }^{1}$ University of Vermont College of Medicine, 226 Health Science Research Facility, Burlington, VT 05405, USA. ${ }^{2}$ SSI Strategy New York, New York, NY, USA. ${ }^{3}$ Lundquist Institute for Biomedical Innovation at Harbor-UCLA Medical Center, Torrance, CA, USA. ${ }^{4}$ Mesoblast, Inc., New York, NY, USA. ${ }^{5}$ UCLA David Geffen School of Medicine, Los Angeles, CA, USA.

Received: 31 December 2020 Accepted: 26 April 2021

Published online: 08 May 2021

\section{References}

1. GBD 2015 Chronic Respiratory Disease Collaborators. Global, regional, and national deaths, prevalence, disability-adjusted life years, and years lived with disability for chronic obstructive pulmonary disease and asthma, 1990-2015: a systematic analysis for the Global Burden of Disease Study 2015. Lancet Respir Med. 2017;5:691.

2. Weiss DJ. Cell-based therapy for chronic obstructive pulmonary disease. Rebuilding the lung. Ann Am Thorac Soc. 2018;15(Suppl 4):S253-9.

3. Broekman W, Khedoe PPSJ, Schepers K, Roelofs H, Stolk J, Hiemstra PS. Mesenchymal stromal cells: a novel therapy for the treatment of chronic obstructive pulmonary disease? Thorax. 2018;73(6):565-74.

4. Galipeau J, Sensébé L. Mesenchymal stromal cells: clinical challenges and therapeutic opportunities. Cell Stem Cell. 2018;22(6):824-33.

5. Liu X, Fang Q, Kim H. Preclinical studies of mesenchymal stem cell (MSC) administration in chronic obstructive pulmonary disease (COPD): a systematic review and meta-analysis. PLoS ONE. 2016;11(6):e0157099. https://doi.org/10.1371/journal.pone.0157099 (eCollection 2016). 
6. Sun Z, Li F, Zhou X, Chung KF, Wang W, Wang J. Stem cell therapies for chronic obstructive pulmonary disease: current status of pre-clinical studies and clinical trials. J Thorac Dis. 2018;10(2):1084-98.

7. Stolk J, Broekman W, Mauad T, et al. A phase I study for intravenous autologous mesenchymal stromal cell administration to patients with severe emphysema. QJM. 2016;109:331-6.

8. Weiss DJ, Casaburi R, Flannery R, et al. A placebo-controlled, randomized trial of mesenchymal stem cells in COPD. Chest. 2013;143(6):1590-8.

9. Abreu SC, Enes SR, Dearbron J, Goodwin M, Coffey A, Borg ZD, dos Santos CC, Wargo MJ, Cruz FF, Loi R, DeSarno M, Ashikaga T, Antunes MA, Rocco PRM, Liu KD, Lee JW, Matthay MA, McKenna DH, Weiss DJ. Lung inflammatory environments differentially alter mesenchymal stromal cell behavior. Am J Physiol Lung Cell Mol Physiol. 2019;317(6):L823-83.

10. Xu AL, Rodriguez LA, Walker KP, et al. Mesenchymal stem cells reconditioned in their own serum exhibit augmented therapeutic properties in the setting of acute respiratory distress syndrome. Stem Cells Transl Med. 2019;8(10):1092-106.

11. Islam D, Huang Y, Fanelli V , et al. Identification and modulation of microenvironment is crucial for effective mesenchymal stromal cell therapy in acute lung injury. Am J Respir Crit Care Med. 2019:199(10):1214-24.

12. Kusuma GD, Carthew J, Lim R, Frith JE. Effect of the microenvironment on mesenchymal stem cell paracrine signaling: opportunities to engineer the therapeutic effect. Stem Cells Dev. 2017;26(9):617-31.

13. Bustos ML, Huleihel L, Meyer EM, et al. Activation of human mesenchymal stem cells impacts their therapeutic abilities in lung injury by increasing interleukin (IL)-10 and IL-1RN levels. Stem Cells Transl Med. 2013;2:884-95.

14. Leuzzi G, Galeone C, Taverna F, Suatoni P, Morelli D, Pastorino U. C-reactive protein level predicts mortality in COPD: a systematic review and metaanalysis. Eur Respir Rev. 2017;26(143):160070. https://doi.org/10.1183/ 16000617.0070-2016.

15. Jing Z, Chun C, Ning S, Hong Z, Bei H, Wan-Zhen Y. Systemic inflammatory marker CRP was better predictor of readmission for AECOPD than sputum inflammatory markers. Arch Bronconeumol. 2016;52(3):138-44. https://doi.org/10.1016/j.arbres.2015.01.011.

16. Nuñez A, Marras V, Harlander M, et al. Association between routine blood biomarkers and clinical phenotypes and exacerbations in chronic obstructive pulmonary disease. Int J Chron Obstruct Pulmon Dis. 2020;31(15):681-90.

17. Man SFP, Connett JE, Anthonisen NR, Wise RA, Tashkin DP, Sin DD. C-reactive protein and mortality in mild to moderate chronic obstructive pulmonary disease. Thorax. 2006;61:849-53.

18. Donohue JF. Minimal clinically important differences in COPD lung function. COPD J Chronic Obstr Pulm Dis. 2005;2(1):111-24. https://doi.org/10. 1081/COPD-200053377.

19. Singh SJ, Puhan MA, Andrianopoulos V, et al. An official systematic review of the European Respiratory Society/American Thoracic Society: measurement properties of field walking tests in chronic respiratory disease. Eur Respir J. 2014;44:1447-78.

20. Armitage J, Tan DBA, Troedson R, et al. Mesenchymal stromal cell infusion modulates systemic immunological responses in stable COPD patients: a phase I pilot study. Eur Respir J. 2018;51(3):1702369.

21. de Oliveira HG, Cruz FF, Antunes MA, et al. Combined bone marrowderived mesenchymal stromal cell therapy and one-way endobronchial valve placement in patients with pulmonary emphysema: a phase I clinical trial. Stem Cells Transl Med. 2017;6:962-9.

22. Shigemura N, Okumura M, Mizuno $S$, et al. Lung tissue engineering technique with adipose stromal cells improves surgical outcome for pulmonary emphysema. Am J Respir Crit Care Med. 2006;174(11):1199-205.

23. Yuhgetsu $H, O h n o ~ Y$, Funaguchi $N$, et al. Beneficial effects of autologous bone marrow mononuclear cell transplantation against elastase-induced emphysema in rabbits. Exp Lung Res. 2006;32:413-26.

24. Zhen G, Liu H, Gu N, Zhang H, Xu Y, Zhang Z. Mesenchymal stem cells transplantation protects against rat pulmonary emphysema. Front Biosci. 2008;13:3415-22.

25. Zhen $G$, Xue Z, Zhao J, et al. Mesenchymal stem cell transplantation increases expression of vascular endothelial growth factor in papaininduced emphysematous lungs and inhibits apoptosis of lung cells. Cytotherapy. 2010;12(5):605-14.

26. Hoffman AM, Paxson JA, Mazan MR, et al. Lung-derived mesenchymal stromal cell post-transplantation survival, persistence, paracrine expression, and repair of elastase-injured lung. Stem Cells Dev. 2011;20(10):1779-92.

27. Huh JW, Kim SY, Lee JH, et al. Bone marrow cells repair cigarette smoke-induced emphysema in rats. Am J Physiol Lung Cell Mol Physiol. 2011;301:L255-266.

28. Katsha AM, Ohkouchi S, Xin H, et al. Paracrine factors of multipotent stromal cells ameliorate lung injury in an elastase-induced emphysema model. Mol Ther. 2011;19:196-203.

29. Schweitzer K, Johnstone BH, Garrison J, et al. Adipose stem cell treatment in mice attenuates lung and systemic injury induced by cigarette smoking. Am J Respir Crit Care Med. 2011;183:215-25.

30. Ingenito EP, Tsai L, Murthy S, Tyagi S, Mazan M, Hoffman A. Autologous lung-derived mesenchymal stem cell transplantation in experimental emphysema. Cell Transplant. 2012;21(1):175-89.

31. Kim SY, Lee JH, Kim HJ, et al. Mesenchymal stem cell-conditioned media recovers lung fibroblasts from cigarette smoke-induced damage. Am J Physiol Lung Cell Mol Physiol. 2012;302:L891-908.

32. Guan XJ, Song L, Han FF, et al. Mesenchymal stem cells protect cigarette smoke-damaged lung and pulmonary function partly via VEGF-VEGF receptors. J Cell Biochem. 2013;114:323-35.

33. Li X, Zhang Y, Yeung SC, et al. Mitochondrial transfer of induced pluripotent stem cell-derived mesenchymal stem cells to airway epithelial cells attenuates cigarette smoke-induced damage. Am J Respir Cell Mol Biol. 2014;51:455-65.

34. Antunes MA, Abreu SC, Cruz FF, et al. Effects of different mesenchymal stromal cell sources and delivery routes in experimental emphysema. Respir Res. 2014;15(118-118):35.

35. Tibboel J, Keijzer R, Reiss I, de Jongste JC, Post M. Intravenous and intratracheal mesenchymal stromal cell injection in a mouse model of pulmonary emphysema. COPD. 2014;11:310-8.

36. Song L, Guan XJ, Chen X, et al. Mesenchymal stem cells reduce cigarette smoke-induced inflammation and airflow obstruction in rats via TGF- $\beta 1$ signaling. COPD. 2014;11:582-90.

37. Li Y, Gu C, Xu W, et al. Therapeutic effects of amniotic fluid-derived mesenchymal stromal cells on lung injury in rats with emphysema. Respir Res. 2014;15:120.

38. Liu HM, Ma LJ, Wu JZ, Li YG. MSCs relieve lung injury of COPD mice through promoting proliferation of endogenous lung stem cells. J Huazhong Univ Sci Technol Med Sci. 2015;35:828-33.

39. Gu W, Song L, Li XM, Wang D, Guo XJ, Xu WG. Mesenchymal stem cells alleviate airway inflammation and emphysema in COPD through downregulation of cyclooxygenase-2 via p38 and ERK MAPK pathways. Sci Rep. 2015;5:8733.

40. Kim YS, Kim JY, Huh JW, Lee SW, Choi SJ, Oh YM. The therapeutic effects of optimal dose of mesenchymal stem cells in a murine model of an elastase induced-emphysema. Tuberc Respir Dis (Seoul). 2015;78:239-45.

41. Kennelly $\mathrm{H}$, Mahon BP, English K. Human mesenchymal stromal cells exert HGF-dependent cytoprotective effects in a human relevant pre-clinical model of COPD. Sci Rep. 2016;6:38207.

42. Li X, Zhang Y, Liang Y, et al. iPSC-derived mesenchymal stem cells exert SCF-dependent recovery of cigarette smoke-induced apoptosis/proliferation imbalance in airway cells. J Cell Mol Med. 2017;21(2):265-77.

43. Cappetta D, De Angelis A, Spaziano G, et al. Lung mesenchymal stem cells ameliorate elastase-induced damage in an animal model of emphysema. Stem Cells Int. 2018;14(2018):9492038.

44. Cheng Y, Gu W, Zhang G, Li X, Guo X. Activation of Notch1 signaling alleviates dysfunction of bone marrow-derived mesenchymal stem cells induced by cigarette smoke extract. Int J Chron Obstruct Pulmon Dis. 2017;27(12):3133-47.

45. Pevsner-Fischer M, Morad V, Cohen-Sfady M, et al. Toll-like receptors and their ligands control mesenchymal stem cell functions. Blood. 2007;109:1422-32.

46. Tomchuck SL, Zwezdaryk KJ, Coffelt SB, Waterman RS, Danka ES, Scandurro AB. Toll-like receptors on human mesenchymal stem cells drive their migration and immunomodulating responses. Stem Cells. 2008;26:99-107.

47. Waterman RS, Tomchuck SL, Henkle SL, Betancourt AM. A new mesenchymal stem cell (MSC) paradigm: polarization into a pro-inflammatory MSC1 or an Immunosuppressive MSC2 phenotype. PLOS ONE. 2010;5(4):10088. https://doi.org/10.1371/journal.pone.0010088. 
48. Romieu-Mourez R, François M, Boivin MN, Bouchentouf M, Spaner DE, Galipeau J. Cytokine modulation of TLR expression and activation in mesenchymal stromal cells leads to a proinflammatory phenotype. J Immunol. 2009;182(12):7963-73.

49. Liotta F, Angeli R, Cosmi L, et al. Toll-like receptors 3 and 4 are expressed by human bone marrow-derived mesenchymal stem cells and can inhibit their T-cell modulatory activity by impairing Notch signaling. Stem Cells. 2008;26:279-89.

50. Weiss DJ, et al. The necrobiology of mesenchymal stromal cells affects therapeutic efficacy. Front Immunol. 2019;4(10):1228. https://doi.org/10. 3389/fimmu.2019.01228.eCollection2019.Review.

51. Abreu SC, Hampton TH, Hoffman E, Dearborn J, Ashare A, Singh Sidhu K, Matthews DE, McKenna DH, Amiel E, Barua J, Krasnodembskaya A, English K, Mahon B, Dos Santos C, Cruz FF, Chambers DC, Liu KD, Matthay
MA, Cramer RA, Stanton BA, Rocco PRM, Wargo MJ, Weiss DJ, Rolandsson ES. Differential effects of the cystic fibrosis lung inflammatory environment on mesenchymal stromal cells. Am J Physiol Lung Cell Mol Physiol. 2020;319(6):L908-25.

52. Enes SR, Hampton TH, Barua J, McKenna DH, dos Santos CC, Amiel E, Asahre A, Liu KD, Krasnodembskaya AD, English K, Stanton BA, Rocco PRM, Matthay MA, Weiss DJ. Healthy versus inflamed lung environments differentially effect MSCs. Eur Respir J. 2021;Ul:33795318.

\section{Publisher's Note}

Springer Nature remains neutral with regard to jurisdictional claims in published maps and institutional affiliations.
Ready to submit your research? Choose BMC and benefit from:

- fast, convenient online submission

- thorough peer review by experienced researchers in your field

- rapid publication on acceptance

- support for research data, including large and complex data types

- gold Open Access which fosters wider collaboration and increased citations

- maximum visibility for your research: over 100M website views per year

At BMC, research is always in progress.

Learn more biomedcentral.com/submissions 